\title{
Student Voting and Apportionment: The "Rotten Boroughs" of Academia
}

On July 5, 1971 President Nixon promulgated the Twenty-Sixth Amendment to the Constitution. ${ }^{1}$ After twenty-nine years of debate, 2 the demise of the magic voting age of twenty-one had come with surprising dispatch-the combined vote of Congress was $494-19,3$ and ratification by the requisite thirty-eight state legislatures took only sixty-seven days. ${ }^{4}$ Before the Amendment passed Congress, attention had turned to the problem of registering the nearly two million college students living away from their parents" homes. "The problem was not solved, then or since, and there now exists a serious conflict between students who insist on participating in local government and those who fear "student take-overs" of local governments. The clash is intensified by the ancient law of voting residence which tends to exclude students from voting in their college towns.

This Note will argue that college-town student voting is constitutionally compelled, since students are viewed as residents of their college towns for purposes of the census and hence for the apportionment of national, state, and local representation. Though the conflict between apportionment and voting entitlement could also be resolved

1. Section 1. The right of citizens of the United States, who are cighteen jears of age or older, to vote shall not be denied or abridged by the United States or by any state on account of age.

Section 2. The Congress shall have the power to enforce this article by appropriate legislation. U.S. CoNST. amend. XXVI.

2. Legislation to lower the voting age had been proposed in every session of Congress since 1942, when Representative Jennings Randolph introduced the first Constitutional Amendment to that effect. 117 Coxc. REc. S2668 (daily ed., March 9, 1971).

3. 117 CoNG. REC. S2886 (daily ed., March 10, 1971) (91-0 in the Senate); 117 Cosc. REC. H1856 (daily ed., March 23, 1971) (400-19 in the House).

4. New York Times, July 1,1971 , at 1 , col. 4.

5: Jannson, The Student Vote, NEw Repuncic, September 19, 1970, at 11; Singer, Student Power at the Polls, 31 OHIO Sr. L.J. 703 (1970).

The precise number of students affected by the law of student residence is difficult to determine as different jurisdictions apply the law in different wajs. See pp. 38.39 infra. Generally, however, the student with a dormitory address is almost certain to face difficulties in registering to vote, so the number of domitory residents may be taken as a rough approximation of the size of the problcm. The estimate that approximatcly' two million students live in dormitories is from CoMmitte oN Electios LAy Rerors of the Young Lawyers Section of the American Bar Associntion, Rerort of thie CostMitife on Student Voting Residence 7 (Preliminary Unofficial Draft, August 1971) [hereinafter cited as A.B.A. REPORT]. 
by changing apportionment methods or the census definition, it will be argued that the proper resolution of the conflict is a change in the law of voting residence.

\section{The Law of Student Residence for Voting Purposes}

\section{A. Background}

There are three fundamental reasons behind the demand of students for college-town registration. First, students from the twenty-four states with no provisions for registration by mail will find it far more convenient to register in college towns than to travel, often more than once, back to their former homes. ${ }^{6}$ Second, many students will find it easier to cast their vote in their college towns: one state has no absentee voting provisions for students; ${ }^{7}$ six others restrict such voting to a limited number of elections ${ }^{8}$ still others make absentee voting extremely difficult by a legal jungle of requesting and filing deadlines. ${ }^{\circ}$ Lastly, many students will feel more involved in and affected by politics in their college towns than in their parents' hometowns. ${ }^{10}$

Political opposition to the registration of students in university towns comes from at least two related sources. First, despite the rapid approval of the Twenty-Sixth Amendment, the fact that voters defeated sixteen of twenty-one state referenda lowering the voting age in the last three years ${ }^{11}$ suggests widespread distrust of the eighteenyear-old vote in general and student voting power in particular. ${ }^{12}$

6. According to a recent compilation of state voting laws, including personal contact with numerous state election officials, the following states wotld not allow a student to register in absentia: Alabama, Arkansas, Connecticut, Delaware, Florida, Gcorgla, Illinois (in some parts of the state), Kentucky, Louisiana, Maryland, Massachusetts, Mississippl, Nevada, New Hampshire, New Jersey, North Carolina, Ohio, Oklahoma, Pennsylvania, Rhode Island, South Carolina, Vermont, Virginia, and Washington. See Youtri Crrizensili! Fund, Inc., The Young Voter's Guide to Voting Rights AND REsidency (August 1971)

For an account of one student's particularly frustrating experience in his attempt to register, see N.Y. Times, July 25, 1971, \& IV, at 4, col. 1.

7. Mississippi law allows absentee voting only by those in the armed forces and related service organizations. MIss. CoDE ANN. § 3196.01 (1956).

8. Delaware (absentee voting restricted to general elections); Maryland (no abscntcc provisions for any municipal elections outside of Baltimore); Massachusetts (no absentce provisions for primaries); New Hampshire (absentee voting limited to the biennial gen. eral election); New Mexico (no provisions for municipal elections); North Carolina (no non-military absentee voting in local primaries). See YouTH CirizensHip Fund, ING., supra note 6 .

9. See, e.g., N.Y. STATE ELEction LAW $§ \S 117-18$ (McKinney 1964).

10. See A.B.A. REPORT, supra note 5, at 16. See also pp. 53.57 infra.

11. Tabulated from 117 CoNc. REc. S2681-84 (daily ed., March 9, 1971) and N.Y. Times, November 5, 1970, at 38, col. 1 .

12. The rapid ratification of the Twenty-Sixth Amendment may be explained in part by the quandry posed by the Supreme Court's approval of the eighteen-year-old votc 
Second, and far more importantly, opposition comes from the older residents of university towns who fear registered students will "takeover" their local government. This concern was expressed during congressional debate on the Amendment:

My principal concern with this particular measure is one that has to do with permitting 18-year-olds to vote, for instance, in local and municipal elections in college towns. For example, what would happen in a community like Urbana, Ill., with an influx of 20,000 or 25,000 students from outside the State coming into that community and being given the opportunity to vote at 18 years of age? For goodness sake we could have these transients actually controlling the elections, voting city councils and mayors in or out of office in a town in which they have a dominant voice. Personally, I feel this is bad. We have seen in Madison, Wis., where in one local election the students of the University of Wisconsin were able to band together and elect several officials who could care less how the city was run and who have no responsibility whatsoever about taxes which have to be raised to fund certain municipal functions in the city. ${ }^{13}$

A supporter of the Amendment agreed that students should not be registered in their college towns, but assured the Congress that the "very, very clear" laws of residence would not permit such a "wrong" result. ${ }^{14}$

Others have been less confident of the sweep of residence law. At least one state legislature enacted a statute aimed at severely restricting college-town registration. ${ }^{15}$ In other states, attorneys-general dusted off textbooks on domicile law and issued mixed opinions on the registration of students. ${ }^{16} \mathrm{And}$, in the context of substantial confusion

for federal elections. Oregon v. Mitchell, 400 U.S. 112 (1970). In order to keep the voting age at twenty-one for state and local elections, the states would have been forced by this decision to maintain costly dual registration and voting procedures. This administrative expense was frequently cited during congressional debate as a major reason for approving the Amendment. See, e.g, 117 Cosc. REc. S2671-79 (daily ed., Nirch 9, 1971). 13. 117 CoNc. REc. H1825-26 (daily ed., March 23, 1971) (remarks of Representative Michel).

14. Id. at 1826 (remarks of Representative Railsback).

15. See, e.g., SESSION LAW NEWS OF NEw YORK Ch. 1096, 1896.97 (Alckinney, 1971).

16. See, e.g., OP. NEv. ATT'Y GEN. No. 48 (October 20, 1971) (endorsing intention tests, but calling for equal application to all); OP. ORE. ATt'Y GEN. No. 6870 (October 20,1971 ) (generally favorable to students, but noting importance of parental control factor); Or. PA. ATT'Y GEN. (September 9, 1971) (generally favorable to students but accepting intention tests); OP. GA. ATT'Y GEN. (August 20, 1971) (generally favorable to students, noting census argument); OP. FLA. ATr'Y GEN. 071-202 (August 3, 1971) (Fviorable to students, stressing equal protection arguments): OP. MAss. ATr'Y GEv. 71/72-3 (July 21, 1971) (accepting the factual basis of residence but arguing for equal application on the basis of the Twenty-Sixth Amendment); Letter from La. Att'y Gen. Jack P. F. Gremillion to Hugh E. Cutrer, Jr., July 13, 1971 (endorsing bona fide residence theory): Letter from S.D. Att'y Gen. to Esther Girard, June 8, 1971 (accepting view student nor- 
about the law, still another group, voting registrars, have become influential in passing on students' right to vote. As the public refusal of one registrar to comply with the opinion of the Massachusetts attorney general ${ }^{17}$ indicates, the attitudes of local election officials have become important constraints on the ability of students to register in their college towns.

In a survey of college-town registrars, the A.B.A. Committee on Election Law Reform found unmistakable opposition to student registriltion. Of twenty-one who replied, only one registrar said student voting was in no way undesirable. The others disapproved because they felt students were not affected by local elections, had different interests or political views than non-students, paid less taxes than permanent residents, or were too concentrated and would thus have too much local political power. ${ }^{18}$ The study further found that this opposition was extremely difficult to control or even accurately ascertain, as few registrars had formal procedures by which student applications were judged.

None of these 24 boards had a set of written rules disclosing the criteria revealed in their responses to the [A.B.A.] questionnaire. No jurisdiction indicated any rule, written or otherwise, as to how the various criteria indicated to be relevant were to be weighed in passing on an application. No jurisdiction appears to have any procedure well designed to elicit from the student all information which might support his claim for registration. ${ }^{10}$

The study committee, after reviewing the stated criteria, had "little if any idea which students would be allowed to vote and which would not." 20 Furthermore, boards within the same state, ostensibly applying the same legal standard, used vastly different criteria and arrived at contrary conclusions in the same case. ${ }^{21}$ The report-which studied only those registrars who felt their procedures were worthy of public scrutiny-concluded that the procedures used in determining student voting residence were

\footnotetext{
mally not a resident because of transiency); Or. CAL. ATr'y GEN. 70/213 (February 17, 1971) (stating that unmarried minor automatically had the residence of his parents) (subsequently overruled, see p. 54 infra); OP. ILL. ATT'Y GEN. (February 3, 1971) (re. stating bona fide residence, intention tests); OP. MONT. ATr'Y GEN. (December 9, 1970) (restating bona fide residence law).

17. New York Times, July 22, 1971, at 21, col. 1.

18. A.B.A. RePORT, supra note 5, at 22-23.

19. Id. at 24.

20. Id.

21. Id. at 25-27.
} 
generally chaotic and fraught with opportunity for discrimination against students of some particular race, party, or cultural persuasion, or against students generally. ${ }^{22}$

\section{B. The Case Law of Student Voling Residence}

The registrars are supported in their opposition to student registration by almost every judicial decision on student voting residence. The frequently cited Fry's Election Case well expresses the general judicial distrust of student voting power:

They [students] are not members of the community among whom they sojourn. They have no common interest; do not intend to live with, or cast their lot among them. They have no proper motive to interfere in their local affairs. On no proper principle of a true residence should the student vote to-day and fasten on the community officers whom the majority do not desire, then graduate to-morrow and be gone.

The great underlying principle of a republic is, that men should be permitted to govern themselves, but not to constrain others. Yet this would be the result of such a shifting vote, which, like the Parthian arrow, pierces as he who casts it flees. ${ }^{23}$

Few courts oppose student voting as openly, but almost every decision has endorsed the common law rule that the typical undergraduate lacks the degree of residence necessary for voting in his college town.

Though only two states qualify the word "resident" in their suffrage statutes, ${ }^{24}$ almost all courts nevertheless begin their decisions on student residence by concluding that for voting purposes "residence" means far more than actual physical presence for the statutory period of time. Some hold that "resident" is a statutory short-hand for "bona fide resident," one who has the intention of making a permanent home in the new area. ${ }^{25}$ Others rely on ancient common

22. 7d. at 23 .

23. $71 \mathrm{~Pa} .302,311$ (1872).

24. The Florida statutes require that the applicant be a "permanent resident," FLA. STAT. § 97.041 (Supp. 1971), while Louisiana law demands that he be an "actual bonn fide resident." LA. REv. STAT. \$ 18.31 (1951). By contrast, twenty-two states carcfully prescribe additional residential qualifications for divorce jurisdiction, most of them speaking of bona fide residence. See ALA. CoDE tit. 34, \$ 27 (1959); ARIz. REv. STAT. ANN. \$25-311 (Supp. I971); Colo. REv. STAT. ANN. \$ 46-1-3 (1963); De. CODE AN. til. 13, \$ 1525 (1953); GA. CODE ANN. \$ 30-107 (1969); HAWAII REv. LAwS \$ 580.1 (1963); IND. ANN. STAT. \$ 3-1203 (1968); KAN. STAT. ANN. \$60-1603 (Supp. 1970); MIIs. Code ANN. \$ 2736 (Supp. 1971); NED. REv. STAT. \$42-303 (1968); N.H. REv. STAT. ANN. \$ 458.5 (1969); N.J: Rev. Stat. \& 2A:34-10 (1952); N.M. STAT. ANN. \$ 22-7-4 (Supp. 1971); N.D. CENT. CODE \$ 14-05-17 (1971); PA. STAT. tit. 23 \& 16 (Supp. 1971); R.I. GEN. LAVS ANN. \$ 15.5.12 (1969); S.D. Comp. Laws \& 25-4-30 (1967); Tex. REv. Civ. Stat. art. 4631 (1960); Utall Code ANN. \$ 30-3-1 (Supp. 1971); VA. CODE ANN. \$ 20-97 (Supp. 1971); W.VA. CODE ANs. \$48.2-7 (Supp. 1971); WIS. STAT. \$247.05 (Supp. 1971).

25. Ptak v. Jameson, 215 Ark. 292, 298-99, 220 S.W.2d 592, 595.96 (1919); Parsons v. People, 30 Colo. $388,392,70$ P. 689, 690.91 (1902). 
law, state constitutions, or ambiguous legislative enactments in holding that "residence" requires an intent to make a new home.20 Through one doctrinal route or another, courts have taken intention to remain as a crucial ingredient of voting residence. ${ }^{27}$

There are two views of the degree of intention necessary for such residence. The more restrictive view demands a clear intent to remain in the area indefinitely and not merely for the purpose of attending college. ${ }^{28}$ The less restrictive view requires only that the student have no definite plans to leave the college town at any time in the future.20 There is no clear pattern favoring either of these theories. ${ }^{.0}$ To the typical student, uncertain about his future plans, the difference between the two views is seemingly critical.

The distinction is more apparent than real, however, since the two theories of requisite intention are implemented by similar criteria of "proof." All of the cases agree that the declaration of the student, even under oath, is not conclusive; ${ }^{31}$ positive facts demonstrating an intent to remain in the town must be presented. ${ }^{32}$ And all agree that the burden is on the student, not the registrar challenging the declaration of intent. ${ }^{33}$ Thus, whichever the requisite degree of intent, the fact that the student has come for the purpose of obtaining an education is said to create a strong presumption that, having obtained his degree, he will leave. Hence, by either standard the student presump. tively is not a resident for voting purposes. ${ }^{34}$

26. Welsh v. Shumway, 232 Ill. 54, 86.88, 83 N.E. 549, 562.63 (1908) (common law); Sanders v. Getchell, 76 Me. 158, 165 (1884); In re Ward, 29 Abb. N. Cas. 187, 20 N.Y.S. 606 (Sup. Ct. 1892); People v. Osborn, 170 Mich. 143, 147.48, 135 N.W. 921, 922.23 (1912); Wilkins v. Ann Arbor City Clerk, 24 Mich. App. 422, 426.27, 180 N.W.2d 395, 397 (1970) (constitutional and statutory constructions).

27. See, e.g., Kegley v. Johnson, 207 Va. 54, 147 S.E.2d 735 (1966)

28. Ptak v. Jameson, 215 Ark. 292, 298.99, 220 S.W.2d 592, 595.96 (1949); Parsons v. People, 30 Colo. 388, 392, 70 P. 689, 690.91 (1902); Vanderpoel v. O'Hanlon, 53 Iowa 246, 249, 5 N.W. 119, $120-21$ (1880); Sanders v. Getchell, 76 Me. 158, 165 (1884); In re Blank. ford, 241 N.Y. 180, 183, 149 N.E. 415, 416 (1925); Kegley v. Johnson, 207 Va. 54, 58, 147 S.E.2d 735, 737-38 (1966).

29. Dale v. Irwin, 78 Ill. 170, 182 (1875); Welsh v. Shumway, 232 Ill. 54, 88, 83 N.E. 549, 562 (1908); Anderson v. Pifer, 315 Ill. 164, 167, 146 N.E. 171, 173 (1925); Yedigo v. Grimes, 113 Ind. 148, 153, 13 N.E. 700, 702.03 (1887); Putnam v. Johnson, 10 Mass. 488, 501 (1813); Berry v. Wilcox, 44 Neb. 82, 89, 62 N.W. 249, 251 (1895); State ex rel. May v. Jones, 16 Ohio App. 2d 140, 142-43, 242 N.E.2d 672, 674-75 (1968).

30. See notes 28 and 29 supra.

31. See, e.g., In re Blankford, 241 N.Y. 180, 183, 149 N.E. 415, 416 (1925); Scibold v. Wahl, 164 Wis. 82,159 N.W. 546 (1916).

32. See, e.g., In re Blankford, 241 N.Y. 180, 183, 149 N.E. 415, 416 (1925).

33. See, e.g., Welsh v. Shumway, 232 IIl. 54, 88, 83 N.E. 549, 562.63 (1908); Sanders v. Getchell, $76 \mathrm{Me}$. I58, 165 (1884); Shaeffer v. Gilbert, 73 Md. 66, 72, 20 A. 494, 495 (1890); Advisory Opinion of the Justices, 46 Mass. 587, 590 (1843); In re Garvey, 147 N.X. $117,119,41$ N.E. 439 (1895); Watermeyer v. Mitchell, 275 N.Y. 73, 76, 9 N.E.2d 783,784 (1937).

34. See, e.g., Welsh v. Shumway, 232 111. 54, 88, 83 N.E. 549, 562.63 (1908); Sanders v. Getchell, 76 Me. 158, 165 (1884); Hoffman v. Bachman, 187 Misc. 799, 80-1, 65 N.X.S.2d 107, 111 (Sup. Ct. 1946). 
The courts have been unclear as to which facts are relevant to prove an intent to remain. For example, the presence or absence of parental control is cited as important by several courts; ${ }^{35}$ but another decision has held that even the complete severance of family ties is not sufficient to prove an intent to remain. ${ }^{30}$ Similarly, courts have often approvingly noted that the student was married and living in his own household..$^{37}$ But marriage is not conclusive. ${ }^{38}$ Other decisions have given weight to owning local property, ${ }^{30}$ claiming local residence for purposes of registering one's car, ${ }^{10}$ obtaining a driver's license, ${ }^{41}$ or paying state and local income taxes. 4 Still others have mentioned local bank accounts ${ }^{43}$ or jobs ${ }^{44}$ as indicia of local residence. But, again, no one fact or set of facts emerges as more important than the others.

This case law presents at least two problems to students attempting to register in their college towns. First, the tests of intent were developed in cases involving litigants quite different from the typical undergraduate. Most of the cases are concerned with older, "quasistudents"-seminarians, ${ }^{45}$ fellows, 40 interns, ${ }^{47}$ veterans on the G.I. Bill $^{ \pm 8}$ - presumably because former age standards disqualified most

35. Dale v. Irwin, 78 Ill. 170, 182 (1875); Welsh v. Shumway, 232 Ill. 54, 88, 83 N.E. 549, 562-63 (1908); Sanders v. Getchell, 76 Me. 158, 166 (1884); Putnam v. Johnson, 10 Mass. 488, 499-500 (1813); Hall v. Schoenecke, 128 M1o. 661, 666, 31 S.W. 97 (189j); Seibold v. Wahl, 164 Wis. 82, 86, 159 N.W 2d 546, 548 (1916).

36. In re Blankford, 241 N.Y. 180, 182, 149 N.E. 415 (1925) (student was a seminarian whose religious vows included a complete repudiation of family ties before entering the seminary.).

37. See, e.g., In re Robbins v. Chamberlain, 297 N.Y. 108, 112, 75 N.E.2d 617, 618 (1947); Reiner v. Board of Elections, 54 Misc.2d 1030, 1031, 283 N.Y.S.2d 963, 964 (Sup. Ct.), aff'd, 28 App. Div. 2d 1095, 285 N.YS.2d 584, aff'd, 20 N.Y.2d 865, 231 N.E.2d 785,285 N.Y.S.2d 95 (1967).

38. Schrum Election Case, $36 \mathrm{~Pa}$. D. \& C. 2d 784, 785 (1965).

39. Reiner v. Board of Elections, 54 Misc.2d 1030, 1031, 283 N.Y.S.2d 963, 965 (Sup. Ct.), aff'd, 28 App. Div. 2d 1095, 285 N.Y.S.2d 584, aff'd, 20 N.Y.2d 865, 231 N.E.2d 785, 285 N.Y.S.2d 95 (1967).

40. Frakes v. Farragut Community School Dist., 255 Iowa 88, 92-93, 121 N.W.2d 636, 638 (1963).

41. Ptak v. Jameson, 215 Ark. 292, 299, 220 S.W.2d 592, 595.96 (1949); Application of Goldhaber, 55 Misc.2d 111, 112, 285 N.YS.2d 747, 748 (Sup. CL. 1967).

42. Frakes v. Farragut Community School Dist., 255 Iowa 88, 92.93, 121 N.W.2d 636, 638 (1963); Sanders v. Getchell, 76 Me. 158, 167 (1884).

43. Reiner v. Board of Elections, 54 Mfisc.2d 1030, 1031, 283 N.Y.S.2d 963, 965 (Sup. Ct.), aff'd, 28 App. Div. 2d 1095, 285 N.Y.S.2d 584, aff'd, 20 N.Y.2d 865, 231 N.E. 785, 285 N.Y.S.2d 95 (1967).

44. Application of Goldhaber, 55 Misc.2d 111, 112, 285 N.Y.S2d 747, 748 (Sup. Ct. 1967).

45. Shaeffer v. Gilbert, 73 Md. 66, 20 A. 434 (1890); Chomeau v. Roth, 230 Mlo. App. 709, 72 S.W.2d 997 (1934); In re Garvey, 147 N.Y. 117, 41 N.E. 439 (1895); In re Blankford, 241 N.Y. 180, 149 N.E. 415 (1925).

46. Application of Goldhaber, 55 Misc.2d 111, 285 N.Y.S2d 747 (Sup. Ct. 1967).

47. Rathbun v. Smith, 175 Misc. 246, 23 N.Y.S.2d 95 (Sup. Ct. 1940).

48. See, e.g., ptak v. Jameson, 215 Ark. 292, 220 S.W.2d 592 (1949); Frakes v. Farragut Community School Dist., 255 Iowa 88, 121 N.W.2d 636 (1963); In re Robbins v. Chamberlain, 297 N.Y. 108, 75 N.E.2d 617 (1947); Hoffman v. Bachman 187 Misc. 799, 65 N.YS.2d 107 (Sup. Ct. 1946). 
undergraduates from voting at all. Because of this inordinate attention to a small portion of the student population, it will be exceedingly difficult for the typical student-unmarried, residing in a dormitory, with few proprietary interests anywhere-to use the tests enunciated by the case law to overcome the presumption against his residencc.

Moreover, none of the decisions suggest a priority system for considering the numerous attributes of residence. Rather, the opinions stress that the factual decision must be an ad hoc one, different with each set of circumstances. ${ }^{40}$ In this way, the law tolerates the almost unlimited discretion of registrars. ${ }^{50}$ Local officials are left free to determine their own lists of relevant criteria and apply them as they desire. Indeed, the courts have endorsed this discretion, holding that the registrar's decision is to be given weight in any judicial review, and that registrars are free of liability for good faith error.51 The law of student residence, tied to the concepts of domicile and future intention, ${ }^{52}$ thus creates a presumption against the typical college student that local registrars are free to use, or abuse, as they see fit.

\section{Constitutional Challenges to the Law of Student Residence}

Since the passage of the Twenty-Sixth Amendment, the law of voting residence has been attacked in both state and federal courts on the ground that its presumption against students and the concomitant special scrutiny given their registration applications, constitutes an arbitrary classification in violation of the equal protection clause. ${ }^{\text {t3 }}$ The demonstrated willingness of the Supreme Court to invalidate

49. See, e.g., Advisory Opinion of the Justices, 46 Mass. 587, 589.91 (1843).

50. See pp. $38-39$ supra.

51. See, e.g., Sanders v. Getchell, 76 Me. 158, 162 (1884).

52. Of course, voting residence law is not unique in its reliance on intent. For cxample, the law surrounding federal diversity jurisdiction relies heavily on intent to determine residency. See, e.g., Williamson v. Osenton, 232 U.S. 619 (1914). However, it is also clear that the law of voting residence can operate independently of other bodies of residence law and that the fact of voting is not controlling on determinations of other types of residence. See, e.g., Lyons v. Borden, 200 F. Supp. 956, 958.59 (D. Hawaii 1961). Thts, the suggestion in the conclusion of this Note that the law of voting residence be modlfied need not necessarily imply an argument for the change of all other bodies of residence law.

53. See Kennedy v. Meskill, Civil No. 14,548 (D. Conn., Sept. 13, 1971) (ordering registrars to ask the same questions of all applicants); Johnson v. Darall, Cause No. IP 71-C-543 (S.D. Ind. 1971) (requiring equal application of bona fide residence test); Anderson v. Brown, 332 F. Supp. 1195 (S.D. Ohio 1971) (striking down a statutory presumption of non-residence); Fair v. Osser, Civil No. 71-2212 (E.D. 1'a. 1971) (stipılated order to the effect that students should be registered if they met tests of residence applied to all applicants); Jolicouer v. Mihaly, 5 Cal.3d 565, 488 P.2d 1, 96 Cal. Rptr. 697 (1971) (invalidating the view of the California Attorney General that all minors automatically had the same residence as their parents); Wilkins v. Bentley, _ Micl.

189 N.W.2d 423 (1971) (requiring the same tests of all applicants); Warden V. Mercer County Bd. of Elections, Civil No. L-1502-71 (Super. Ct. N.J. 1971) (order requiring the same intention test of all applicants). 
suffrage restrictions which do not meet the "compelling state interest" test $^{\text {ts }}$ has led some commentators to conclude that such unequal application of the law of voting residence will not withstand constitutional scrutiny..$^{55}$ However, a closer examination indicates that an equal protection claim of this kind may be unsuccessful.

There is language in the two major cases cited by opponents of student residence law which may be read as endorsing the present system. In Carrington $v$. Rash, ${ }^{56}$ a 1965 decision, the Court invalidated a Texas statute that established an irrebuttable presumption that servicemen stationed in Texas were not residents. The Court stressed, however, that the state was free to require that "all military personnel enrolled to vote be bona fide residents," and that they all have "the intention of making Texas their home indefinitely." writing for the Court, also agreed with Texas decisions which had held that "the declarations of voters concerning their intent to reside in this state and in a particular county is often not conclusive," and that therefore, "election officials may look to the actual facts and circumstarices" behind the application. ${ }^{68}$ Finally, the Court approvingly cited statutes in other states which provided for special treatment for students and servicemen." The Court argued that these "reasonable and adequate steps" were permissible as the target populations were given "an opportunity to show the election officials they are bona fide residents." 60 Thus, Carrington suggests that a presumption against the voting residence of a certain class of citizens is valid so long as there is some possibility of controverting it.

In Evans v. Cornman, ${ }^{61}$ a 1970 decision, the Court appeared to be troubled by the ambiguous intention tests of bona fide residence theory, but nevertheless adhered to the view of Carrington that an equal application of such tests is permissible. Justice Marshall, writing for a unanimous Court, rejected the finding of a Maryland registrar that the residents of the National Institute of Health enclave were not voting residents. He found that there were "numerous and vital

54. See Phoenix v. Kolodziejski, 399 U.S. 204 (1970); Cipriano v. City of Houma, 395 U.S. 701 (1969); Kramer v. Union Free School Dist. No. 15, 395 U.S. 621 (1969).

55. Singer, Student Power at the Polls, 31 Owo ST. L.J. 703 (1970); Comment, Student Voting Rights in University Communities, 6 HARv. CIV. RIGIrs.Civ. LIB. L. REv. 397 (1971); Note, Restrictions on Student Voting: An Unconstitutional Anachronism?, $4 \mathrm{U}$.

MICH. J. L. REFORMI 215 (1970).

56. 980 U.S. 89 (1965).

57. Id. at 93-94.

58. Id. at 95 .

59. Id. at 91-92 n.3.

60. Id. at 95.96.

61. 398 U.S. 419 (1970). 
ways in which the NIH residents are affected by electoral decisions." As examples, Justice Marshall noted that the NIH employees paid state income, sales, and excise taxes, were covered by state unemployment and workmen's compensation laws, were required to register their cars locally and obtain state driver's licenses, were subject to the jurisdiction of state courts, and sent their children to local schools. ${ }^{\text {oj }}$ This analysis could be read to suggest that the Court was moving away from the traditional tests of voting residence by substituting concrete indicia of residence for the vague, intent-oriented standard of "bona fide residence." But Justice Marshall clearly destroyed any such inference:

Maryland may, of course, require that "all applicants for the vote fulfill the requirement of bona fide residence." 0.4

That requirement, of course, provides the basis for the presumption against student residence.

Even if the Court does prohibit the unequal application of the test of bona fide residence, the plight of the student voter may not be greatly improved. Under just such an equal application court order, ${ }^{08}$ the registrars of New Haven developed an elaborate questionnaire embodying most of the tests of bona fide residence and applied them to all applicants. ${ }^{60}$ The registrars then failed fifty-nine per cent of the

62. Id. at 424.

63. Id.

64. Id. at 421, citing Carrington v. Rash, 380 U.S. 89, 96 (1965).

65. Kennedy v. Meskill, Civil No. 14,548 (D. Conn., memorandum and order filed Sept. 13, 1971).

66. The following questionnaire was required of all applicants in New Haven in the autumn of 1971:

QUESTIONS TO BE ASKED IN CONNECTION WITH APPLICATIONS HOR REGISTRATION AS A VOTER IN THE CITY OF NEW HAVEN

I. What is your date of birth?

2. Are you a United States citizen?

3. What is your present address?

4. How long have you lived at that address?

5. At what other addresses, if any, have you lived in New Haven and during what periods?

6. How long have you lived in New Haven?

7. Do you regard New Haven as your home?

8. Is there any other place which you regard as your home?

9. Have you voted or registered to vote in any other place during the last six months?

10. (a) Have you voted or registered to vote in any other place during the last two years?

(b) If so, do you have any present intention to vote there again?

11. During the past six months have you claimed any other address as your place of residence for any reason?

12. What is your occupation?

13. (a) Where do your parents live? 
student applicants, while denying only three per cent of the non-students. ${ }^{67}$ Even allowing for a certain degree of bias against students, it appears that most students cannot demonstrate an intention of remaining indefinitely as convincingly as the average non-student.

What is clearly needed, if students are to be registered in their college towns, is a reevaluation of the concept of voting residence itself. The remainder of this Note will argue that such a reevaluation is due because the census, and hence apportionment plans, hinge residence not on future intention, but on a simple test of physical presence.

\section{The Census Definition of Student Residence}

Until 1950, the Bureau of the Census considered college students to be residents of their parents' homes. But in that year, the Bureau began to enumerate students as college-town residents, a practice continued in the 1960 and 1970 censuses. ${ }^{\circ 8}$ Given the subsequent development of an apportionment theory which makes census population the standard for most allocations of national, state, and local legislative power, this Bureau decision was of no small consequence.

(b) When, if at all, have you stajed at jour parents' home during the last two years?

14. How long do you expect to stay in New Haven?

15. Do you or your spouse own a car and, if so, where is it registered and where is it taxed?

16. What address appears on the registration?

17. Do you have a driver's license and, if so, what state issued the license?

18. What address appears on the license?

19. If registered for the draft at a place other than New Haven, what is the number and location of your draft board and have you notified your draft board that you have moved and your permanent residence is now in New Haven?

20. Have you voted anywhere other than New Haven in 1969 or 1970, and if you have, list the places and dates where you have voted?

21. Are you eligible to vote anywhere other than New Haven in 1971?

22. If you voted at a place other than New Haven in 1969 or 1970 , and if you are eligible to vote at a place other than New Haven in 1971, have you notified the voting officials at this other location to remove your name from the voting list?

23. Do you own any real estate and if so where is it located?

24. Do you own any property other than real estate and if so, where is it located and, if taxable, where is it taxed?

25. Where do your parents live?

26. Have you used your parents' address for your driver's license, your car regis. tration or your voting address during the past two years?

67. Supplementary Memorandum in Support of Plaintirrs Motion to Punish De. fendants for Contempt and Related Relief at 2, Kennedy v. Meskill, Civil No. 14,548 (D. Conn. 1971). Counsel for plaintiff also noted that as the "student" category included between thirty to fifty high school students who had lived in New Haven all of their lives and hence were quickly accepted, the actual percentage of college students rejected was considerably higher than fifty-nine per cent. Id. at 13 .

68. U.S. Bureau of the Census, Usual Residence of College Students, May 2, 1966, at 2 (mimeographed release). 


\section{A. The "Rotten Boroughs" of Academia}

Even before the reapportionment cases $^{\mathrm{e} 0}$ it was generally held that population, as defined by the census, was the proper base for legislativc apportionment. The Constitution ${ }^{70}$ and congressional enactments ${ }^{71}$ had developed a precise formula, based on census population, for the allocation of United States Congressmen. A survey of the states a few months before the reapportionment decisions found that thirty-six also based their apportionment formulas on total population..$^{72}$ Seven others ${ }^{73}$ excluded minor groups from the census definition of resident population, but none of these treated students in any special manner. Thus, for apportionment purposes, by 1964 forty-three states included all students residing within the state and correspondingly excluded any student who had left the state to attend college elsewhere. Since 1964 the trend towards a simple total population standard has continued. ${ }^{74}$ At present, only two states-Hawaii ${ }^{75}$ and Vermont ${ }^{70}-$

69. Reynolds v. Sims, 377 U.S. 533 (1964); WMCA, Inc. v. Lomenzo, 377 U.S. 633 (1964); Maryland Comm. v. Tawes, 377 U.S. 657 (1964); Davis v. Mann, 377 U.S. 678 (1964); Roman v. Sinnock, 377 U.S. 695 (1964); Lucas v. Colorado General Assembly, 377 U.S. 713 (1964).

70. U.S. CONST. art. I, § 2; amend. XIV, § 2.

71. 2 U.S.C. $\$ 2(b)(1970)$.

72. Silva, One Man, One Vote and the Population Base, in REPREsentation AND MisRepresentation 57 (R. Goldwin ed. 1966), citing Council of State Governatents, THE' BOOK OF THE STATES 1964-1965, at 62-63 (1964).

73. Id. at 57-58.

74. The legislatures of Rhode Island and Massachusetts, recognizing the inequities in apportioning on the basis of registered voters, have essentially enacted the "Onc mall, one vote" standard based on total population. See R.I. GEN. LAwS ANN. $\$ 22.2 .5(1968)$ and Mass. Public Act $877, \S 1$ (1967). The Indiana legislature recently did the same by apportioning on the basis of census inhabitants. See Ind. Public Acts 4 and 5 (1971). (But see IND. Const. art. 4, \$ 5, which bases apportionment on "male inhabitants over 21." This archaic formtla is in the process of being repealed. See Ind. Sen. Joint Res. No. 26, Acts 1969, ch. 464, at 1858). See generally Whitcoinb v. Chavis, 403 U.S. 124 (1971). Arizona's legislature has been apportioned on a census population basis pursuant to a federal district court order invalidating its old, gubernatorial vote standard. See Klahr v. Goddard, 250 F. Supp. 537 (D. Ariz. 1966). Finally, Tennessee courts and the statc legislature have interpreted the base of "qualified voters" to be total census population of voting age so that all students of voting age attending Tennessee colleges are cont. sidered "qualified voters" whether or not they have been allowed to register. See Baker v. Carr, 369 U.S. 186, 189 n.4 (1962); Tenn. Acts [1965 E.S.] ch. 3, § 1.

75. Hawall Const. art. III, $\S 4$.

76. The Vermont Constitution specifies that each town is to have one scat in the lower house, but this formula was ruled unconstitutional, for obvious reasons, by a federal district court. See Buckley v. Hoff, 234 F. Supp. 191 (D. Vt. 1964), modified on oilher grounds and aff'd sub nom. Parsons v. Buckley, 379 U.S. 359 (1965). The 1965 apportion. ment act-using registered voters as the base-was then approved by the same court in Buckley v. Hoff, 243 F. Supp. 873, 875.76 (D. Vt. 1965).

The value of Buckley $I I$ as an endorsement of the registered voters base is quêstionable as it was decided before Burns v. Richardson, 384 U.S. 73 (1966), in a time of uncertainty over the demands of the equal protection clause when applied to legislative apportion. ment. See pp. 50-51 infra. Indeed, the court in Buckley II noted some of the objections to using registration figures as a base and approved their use largely on the grounds that in comparison to the old clearly malapportioned plan, the new procedure was an improvement. See Buckley v. Hoff, 243 F. Supp. 873, 876-78 (D. Vt. 1965). 
allocate state representatives on a base (registered voters) that does not automatically count students along with all other residents.

Thus, the existing law of student voting residence intersects with the practice of apportioning legislators on a population basis ${ }^{i \pi}$ to produce two troublesome anomalies. First, some individuals considered to be residents for the purpose of allocating political power are denied access to that power by the strictures of the law of bona fide residence. The Court in Evans noted this conflict when it cited the fact that the NIH employees were residents of Maryland for apportionment purposes as one factor favoring their registration as residents of that state. ${ }^{\mathbf{7 8}}$

Second, and more disturbing, continuance of the traditional standards of student voting residence will continue to dilute the votes of those who do not live in the few towns with a substantial supply of student "non-residents" on hand. Such dilution, based solely on geography, was, of course, the prime target of the early reapportionment decisions. ${ }^{\text {ig }}$

A few examples indicate that this dilution is not de minimis. On the local level, college towns which allocate seats in their municipal legislatures on the basis of ward or precinct population are almost certainly malapportioned. In New Haven, for example, each alderman represents approximately 4600 residents. ${ }^{80}$ Yet, in reality, the alderman from District 1 represents 800 "residents" and 3800 Yale undergraduates $^{81}$ who are not, according to New Haven voting officials, residents of the city. ${ }^{82}$ A citizen who lives in District 16, with 4600 true residents and no Yale students, thus has only about seventeen per cent the voting power of a citizen in District 1 . New Haven is actually a poor example of this "rotten borough" phenomenon, as Yale students account for only about five per cent of the total city population. ${ }^{83}$ Far greater local apportionment problems exist in other towns, where

77. See Wesberry v. Sanders, 376 U.S. 1 (1964); Reynolds v. Sims 377 U.S. 533 (1964): Avery v. Midland County, 390 U.S. $474,480-81$ (1968).

78. Evans v. Cornman, 398 U.S. 419, 421 (1970).

79. See, e.g., Reynolds v. Sims, 377 U.S. 533, 561-68 (1964).

80. New Haven has thirty aldermen to divide among its population of 137,707 or a theoretical ratio of one alderman for every 4590 inhabitants. See U.S. Bureau of tile Census, Number of Inhabitants, Connecticut PC(1)-A8, at 8-11 (April 1971).

81. The 3800 Yale undergraduates include only those living in twelve residential colleges within the aldermanic district boundaries.

82. The refusal of New Haven election officials to register almost all Yale students led to a court challenge and subsequent administrative maneuvering. See generally New Haven Register, September, 1971; pp. 44.45 and notes 65.67 supra.

83. Yale has a total enrollment of 8665 full-time students. THE WorLd Atsanac 159 (1971). 
students comprise between twenty and thirty per cent of the population. ${ }^{84}$

Student concentrations also seriously affect the apportionment of many state legislatures. In the most recent Connecticut reapportion. ment plan, the town of Mansfield received one state representative for its 20,000 census residents. ${ }^{85}$ But at least 8,000 of these were stu1dents at the University of Connecticut ${ }^{86}$ who are, according to a restrictive reading of state law, "non-residents." Thus, the 12,000 "real" residents of Mansfield receive the same degree of representation as 20,000 residents of any other Connecticut town, a deviation of 1.67 to $1^{87}$ _far beyond de minimis limits. ${ }^{88}$ And again, even more significant deviations can be found in other states. In New Hampshire, for example, the number of students attending both Dartmouth College and the University of New Hampshire is almost twice the number of people represented by a seat in the New Hampshire house. ${ }^{80}$

Finally, if we accept the theory that students are residents of their home states, the census definition of population even results in the misallocation of Congressmen. In 1970, both Connecticut and Oklahoma received six Congressmen; but, if the logic of the voting residence decisions were to govern apportionment, Connecticut would be entitled to seven Congressmen and Oklahoma only five. ${ }^{.0}$ Other

84. Athens, Ohio (Ohio University); College Park, Maryland (University of Maryland); Ithaca, New York (Cornell University); Bloomington, Indiana (Indiana University); Kcnt, Ohio (Kent State University); Pullman, Washington (Washington Statc University) Lafayette, Indiana (Purdue University); Newark, Delaware (University of Delawarc); and Vermillion, South Dakota (University of South Dakota) all have significant student poptl. lations and, according to the latest compilation of the International City Manager's $\Lambda$ s. sociation, a ward system of local apportionment. See A.B.A. REroRT, supra notc $5, A$. pendix B; The International City Manacer's Association, The Municipat YeAk Book 1968, at 64-130.

85. See Hartford Courant, October 1, 1971, at 52; U.S. Burenu of tite Census, Nunincr of INHABITANTS, ConNecticut PC(1)-A8, at 8-11 (April 1971).

86. A.B.A. REPORT, supra note 5 , at 55 .

87. The deviation is that between the most and least populous districts, the traditional test of malapportionment. See, e.g.; Reynolds v. Sims, 377 U.S. 533, 545.46 (1964).

88. See Kilgarin v. Hill, 386 Ü.S. 120, 124 (1967) (1.21 deviation not de minimis); Swann v. Adams, 385 U.S. 440, 442-45 (1967) (1.30 deviation invalid). See also Kirkpatrick v. Preisler, 394 U.S. 526, 531 (1969) (1.06 congressional deviation invalid).

89. The New Hampshire House has 400 members representing a population of al). proximately 723,000 , or one seat for every 1800 residents. See THE CounciL of Srail Governments, THE Book of the STATEs 1970-1971, at 83 (1970); THE Wokld Almanac 454 (1971). The University of New Hampshire has 3647 residential students; Dartmouth College has 3100 full-time students. 2 Collece BLuE Book 1969-70, at 313,315 .

90. Seats in Congress are allocated to the states according to a statistical method known as the "method of equal proportions." 2 U.S.C. $\$ 2(\mathrm{~b})(1970)$. For a complete explanation of the method, see E. Huntington, Methods of APrortionment, S. Doc. No. 76.301, 76th Cong., 3d Sess. 3-7 (1940); L. Schmeckebeir, Congressional Apportionment 21-31 (1911).

The method's formula, when applied to the census population of cach statc yiclds a series of "priority numbers." After one seat is allocated to cach statc, U.S. CoNsr. art. I, $\$ 2$, cl: 3 , the 385 highest numbers each carn one seat.

When the formula was applied to the populations of Oklahoma and Connecticut, it 
states such as Massachusetts, New York, New Jersey, and Illinois-each with a net gain or loss of more than 20,000 students-might be similarly affected in future congressional allocations. ${ }^{01}$

There are three possible solutions to this conflict between the manner of apportionment and the law of voting residence. First, the apportioning authority, either legislative or judicial, could carefully factor out student concentrations when allocating representatives. Second, the Census Bureau could revert to its pre-1950 position and enumerate all students as residents of their parents' homes. Finally, the law of voting residence could be clarified and modernized so as to coincide with the census definition.

\section{B. The Factoring of Student Concentrations}

Presently, the legislature of only one state, New Hampshire, has the explicit authority to make "suitable adjustments to the general census of inhabitants . . . on account of non-residents temporarily residing in this state." 92 But the question of excluding "non-residents" from an apportionment base has been before the Supreme Court at least three times. In Davis v. $M \mathrm{Kann}^{93}$ Virginia officials contended that the underrepresentation of two districts was justified on the grounds that both contained large numbers of military personnel. Chief Justice Warren summarily rejected this argument, holding, inter alia, that the assumption that all servicemen were non-residents, "without more being shown," was a form of impermissible occupational discrimination. He further found that the Virginia legislature had not disfavored military registration in the past, nor had it consistently factored servicemen out of other reapportionments. ${ }^{01}$

was computed that Oklahoma's sixth seat had a priority number of $472,043-2,585,485$ (Oklahoma's population) times a statistical multiplicr of .18257419 and Connecticut's seventh seat had a number of 470,731 - $3,050,693$ times a multiplicr of .15430395 . Sce U.S. Department of Commerce, Bureau of the Census, Table of Miultiplers for APPORTIONMENT (November, 1970).

But if the net increase in Oklahoma's population duc to student migration, 2,591 in 1963 , is subtracted and the net loss to Connecticut's population, 13,709, is added, nev: priority numbers of $471,969-2,582,895$ times $.18257+19$-for Oklahoma's sixth seat and 472,847-3,064,412 times. 15430335 - for Connecticut's seventh seat emerge, and thus Connecticut and not Oklahoma would get the seat in question. This argument is theoretical insofar as the student migration figures are not current. Howerer, the historical trend makes it likely that, in 1970, Connecticut's loss due to student migration was even greater than 13,000 and Oklahoma's gain was more than 2500. See C. Gossuras, et al., Migration of College and University Students in tile United States 110.11 (1968).

91. See id.

92. N.H. CoNst. pt. 2, art. 9-a. This provision was limited to a carcfully conducted, state-wide, systematic factoring by a recent advisory opinion of the Nicw Hampshire Supreme Court, In re Opinion of the Judges, 276 A.2d 825,828 (1971). Given the problems involved with such a procedure, the New Hampshire exception is of questionable value. See pp. $50-51$ infra.

93. 377 U.S. 678 (1964).

94. Id. at 691-92. 
In 1966 the Court was again faced with the issue of excluding "nonresidents" in Burns $v$. Richardson, ${ }^{05}$ a challenge to the use of registered voters as an apportionment base in Hawaii. Justice Brennan began by asserting that "the equal protection clause does not require the states to use total population figures derived from the federal census" as the only permissible apportionment standard. ${ }^{06} \mathrm{He}$ conceded that Hawaii had "special population problems" with its great number of servicemen and that it was factually demonstrated that the number of registered voters was, in this very special case, a better approximation of true state citizen population than total population as defined by the census. ${ }^{97}$ On this ground, the Court approved the use of registered voters as an apportionment base. ${ }^{98}$ However, Justice Brennan was quick to limit the decision by stressing that if it were shown that the registered voter base differed from population because of other factors, such as voter apathy among the poor, and thus was not closely related to total state resident population, it would no longer be al permissible apportionment base. ${ }^{00}$

Thus, while Burns recognizes that apportionment on the basis of census population in an area with a significant number of "non-residents" is not compelled, it allows a legislature to use another apportionment base only when it can be demonstrated that such a base consistently "approximates distribution of state citizens." 100 Lower courts, applying Burns, have stressed this requirement in rejecting a majority of the apportionment plans based on voter registration.101 Given the small likelihood that voter registration rates will be constant throughout a state, Burns can be viewed as an extremely limited man. date for factoring.

In Kirkpatrick v. Preisler, ${ }^{102}$ a 1969 decision, the Court limited Burns still further by rejecting the factoring of both students and servicemen in a Missouri reapportionment plan. Justice Brennan

95. 384 U.S. 73 (1966).

96. Id. at 91 .

97. Id. at $94-95$.

98. Id. at $97 \mathrm{n} .27$

99. Id. at 96.97. See also Ely v. Klahr, 400 U.S. 108, 115 n.7 (1971).

100. 384 U.S. at 95 .

101. See Klahr v. Williamson, 313 F. Supp. 148, 150 (D. Ariz. 1970), aff'd stub nom. Ely v. Klahr, 400 U.S. 108 (1971); Preisler v. Mayor of City of St. Louis, 303 F. Supp. 1071 (E.D. Mo. 1969); Kapral v. Jepson, 271 F. Supp. 74, 80 (D. Conn. 1967); Bannister v. Davis, 263 F. Supp. 202 (E.D. La. 1966); Calderon v. City of Los Angeles, 4 Cal.3d 251, 481 P.2d 489, 93 Cal. Rptr. 361 (1971); Hartman v. Denver, 165 Colo. 565, 440 P.2d 778 (1968); Opinion of the Justices to the Senate, 353 Mass. 790, 230 N.E.2d 801 (1967); Warren v. City of North Tonawanda, 60 Misc.2d 593, 303 N.Y.S.2d 945 (Sup. Ct. 1969); Penn Hills Twp. Redivision, 216 Pa. Super. 327, 264 A.2d 429 (1970). 102. 394 U.S. 526 (1969). 
stressed that any factoring, in addition to being closely related to true state population, must be conducted in a systematic and consistent manner not merely in areas of large "non-resident" concentrations but throughout the entire area to be reapportioned, in this case the entire state. ${ }^{103}$ Kirkpatrick thus essentially demands a special houseby-house state census, an almost certainly prohibitively expensive procedure, before any factoring can be done. ${ }^{10 t}$

It therefore appears unlikely that the problem of concentrations of "non-resident" students will be solved by simple factoring, for unless a state can squeeze itself into the very narrow exception of Burnsapproved only on an interim basis even for Hawaii ${ }^{103}$-it will be forced into a costly special census in order to determine the residence of every state inhabitant. Moreover, college towns may be less than eager to see implemented a procedure which, by excluding students from their population, will cost them political representation and power. Thus, factoring students out of the general census population is likely to be unpopular and extremely difficult to achieve.

\section{Changing the Census Definition}

Census Bureau documents indicate that the decision to enumerate students as college-town residents was made for four reasons. First, experience had shown that relying on parents to determine the residence of students was a haphazard procedure which often produced inaccurate counts. ${ }^{106}$ This finding is not surprising in view of the confusing standards that proliferate when the simple test of physical presence is abandoned. ${ }^{107}$

Second, the Bureau was troubled by the fact that other groups in society with two "homes"-servicemen, workers on temporary assignment, inmates of prisons and hospitals-were enumerated as residents of their present physical homes, not of their former "real" ones. The Bureau felt that there was simply no reason for continuing the inconsistent treatment of students. ${ }^{108}$

Third, the Bureau found that counting students as residents of

103. Id. at 535 .

104. The special state census would be necessitated as the federal census does not inquire into an individual's intention to remain.

105. Burns v. Richardson, 384 U.S. 73, 85-80 (1960).

106. Dep't of Commerce, Bureau of the Census, Usual Residence of Students, Oct. 14, 1948, at 1 (Memorandum to the Technical Advisory Committe on Population for the Seventeenth Decennial Census).

107. See pp. 40-41 supra.

108. Dep't of Commerce, Bureau of the Census, Usual Residence of College Students, May 2, 1966, at 1-2 (release). 
their former homes resulted in unrealistic population figures for college towns and thus frustrated a primary purpose of the census, the allocation of public resources and services. ${ }^{100}$ In view of the many federal and state grant-in-aid programs which are tied to census figures, ${ }^{110}$ this contention seems justified. As a restatement of the census position argued, the new rule "makes good economic sense," as students "live in their college communities, draw on their resources [and] rely on their services ...."111

Finally, the Census Bureau concluded that it was simply unrealistic to continue to assume that the student was not a true college-town resident because he might have some intention of leaving in the future. As the Bureau explained rather tautologically:

The census counts people where they live. That's why college students are counted in the place they live while attending school .... For that is where they live. ${ }^{112}$

The Bureau's view has been judicially endorsed. In Borough of Bethel Park v. Stans, ${ }^{113}$ U.S. District Judge Wallace Gourley held that the Bureau decision was not only within the statutory discretion of the Director but was also fundamentally correct.

Judge Gourley accepted the Bureau's finding that the prior practice led to underenumeration and misallocation of students ${ }^{114}$ and that there was no convincing reason for continuing to treat students differently from other "equally transient" groups. ${ }^{115} \mathrm{He}$ also found that the assumption that students would return to their parents' homes was simply invalid.

109. Dep't of Commerce, Bureau of the Census, Usual Place of Residence, for Those in College, Service, Institutions, Aug. 31, 1971, at 2 (typed release).

110. See, e.g., 20 U.S.C. § $1243(\mathrm{a})(2)(1970)$ (vocational education grants); 28 U.S.C. \& 104(b) (1970) (highway fund payments); 33 U.S.C. $\$ 1157$ (c) (1970) (water pollution abatement facilities); 42 U.S.C. $\$ 291(\mathrm{~b})$ (1970) (hospital construction grants); 42 U.S.C. $\S 621$ (1970) (child welfare and day care grants); 49 U.S.C. $\$ 1105$ (a) (1970) (airport construction grants). In addition both major versions of proposed federal revenue sharing base their grants on state population. See M. Levy \& J. Torres, Federal Revenve Silarino with the States: Problems and Promises 83, 90 (1970).

For an increasingly common example of a state aid formula based on poptulation sce N.Y. State Fin. Law § 54 (McKinney Supp. 1971).

111. Dep't of Commerce, Bureau of the Census, Usual Place of Residence, for Those in College, Service, Institutions, supra note 109 , at 2.

112. Id. at 1 .

113. 319 F. Supp. 971 (W.D. Pa. 1970), aff'd, 449 F.2d 575 (3rd Cir. 1971). The Third Circuit also considered the conflict between the census and state suffrage law. 'The court rejected the contention that this inconsistency invalidated the census definition, suggcsting that the problem could be solved by state apportioning authoritics. $I d$. at 582.89 n.4. But see pp. 49.51 supra.

114. 319 F. Supp. 971,978 (W.D. Pa. 1970).

115. Id. at 979 . 
[C]ollege students are a transitional group in the population, and many will not return to the address of their parents .... [S]ome will not return to their home states. Of those who will return to a home state ... there will be, nevertheless, many who acquire residences in congressional and state legislative districts and political subdivisions other than the one in which they once resided.110

Finally, and perhaps most significantly, Judge Gourley suggested the necessary connection between residence and the functions of local government, concluding:

The communities in which these persons are residing must plan and develop their public resources to provide for all residents. No abuse of discretion is found in enumerating these persons as inhabitants of these communities rather than as residents of a presumptive home to which many may not be expected to return. ${ }^{11 i}$

If, as Judge Gourley found, the census is correct in its assumption that the student is more affected by the government of his college town than that of his parents' home, both apportionment and basic democratic theory demand that he be allowed to vote for the elected officials of the college-town government. The fact that the typical residential student spends at least seventy-five per cent of his time in his college town would appear to settle the issue in favor of the census. But supporters of traditional voting residence law argue that there may be additional factors which tend to controvert this conclusion. We will examine four factors commonly cited to justify the traditional law of student voting residence. In each case it will be argued that the putative justification fails, and that the census definition of residence is superior.

\section{The Factors Cited as Opposed to the Census Definition}

\section{The Assumption of Parental Control}

A major objection to the census definition of student residence is that the student is still under the control of parents residing elsewhere, who may influence his voting decisions. ${ }^{118}$ The most obvious rebuttal to this argument is that the Twenty-Sixth Amendment presumes that

116. Id. at 978 .

117. Id. at 979 .

118. See, e.g., Putnam v. Johnson, 10 Mass. 488, $499-500$ (1813). For a possible explanation of the relevance of parental control, see Jolicouer $v$. Mrihaly, $5 \mathrm{Cal} 3 \mathrm{~d} 565$, 488 P.2d I, 96 Cal. Rptr. 697 (1971). 
all those over eighteen are, at least for voting purposes, sufficiently free to exercise choice. The California Supreme Court recently used precisely this reasoning in rejecting the contention of the state attorney general that all minors automatically had the residence of thcir parents because they were legally unemancipated.110

But even before the passage of the Amendment, it was clear that the student of today has far more rights and is far less subject to parental control than his nineteenth century counterpart. The Amendment itself was in part a response to the fact that state governments had granted eighteen-year-olds a significant degree of indiviclual frecdom, recognizing that they were old enough to govern many of their own actions. ${ }^{120}$ Thus even the student who lived at home was recognized to be less subject to parental control.

Furthermore, recent developments in education law have denied even the vicarious exercise of parental control over students living away from home. Even in the nineteenth century it was obvious that a parent could not directly control a child attending school in another town or state. But until recently, the parent could exercise control, at least in legal theory, by vesting the college administration with his parental power. The administration would then act in place of the parent, in loco parentis, and the courts would not interfere with even the most arbitrary exercise of such vested parental rights and respon. sibilities. As one court, upholding the expulsion of a student for "ringing cowbells and parading in the halls of the dormitory at forbidden hours," put it:

As to mental training, moral and physical discipline, and welfare of pupils, college authorities stand in loco parentis and in their discretion may make any regulation for their government which a parent could make for the same purpose, and so long as such regulations do not violate divine or human law, courts have no more authority to interfere than they have to control the domestic discipline of a father in his family.121

Today, however, in loco parentis, as applied to college students, is virtually dead. ${ }^{122}$ Courts oversee and if necessary overturn university actions to insure that due process has been afforded to affected stu-

119. Jolicouer v. Mihaly, 5 Cal.3d 565, 488 P.2d 1, 96 Cal. Rptr. 697 (1971).

120. See generally I. SLOAN, YoUTH AND THE LAW (1970).

121. John B. Stetson Univ. v. Hunt, 102 So. 637, 640 (Fla. 1924).

122. See Zanders v. Louisiana State Bd. of Educ., 281 F. Supp. 747, 755.56 (W.D. La. 1968); Buttny v. Smiley, 281 F. Supp. 280, 286 (D. Colo. 1968). 
dents. ${ }^{123}$ The college-student relationship is now viewed as a contractual one in which each side has certain rights and responsibilities.124 The university administration has neither the right nor the responsibility for regulating student conduct beyond establishing academic standards and protecting the rights of others within the scholastic community. ${ }^{125}$ Thus, the law no longer views the student as a child living temporarily with a guardian who exercises the will of a missing parent but rather as an individual independently pursuing a career free from parental control. This view supports the census decision to treat students exactly as it treats others, such as businessmen, who are working at a temporary position.

\section{The Assumption of Immunity from the Local Police Power}

A second objection to the census definition of student residence is that colleges and universities are privileged sanctuaries from local police power. Clearly, the degree to which a resident is affected by the state and local police power is an important element in determining his "interest" in local political affairs. In Evans, the Court took great pains to show that the NIH residents were, to a limited degree, under the local police power of Maryland and therefore had an interest in the outcome of local elections. ${ }^{100}$ By comparison, the student is far more affected by the exercise of local police power. Unlike his British counterpart of days past, the American student is completely subject to local authority. ${ }^{127}$ He has none of the scholarly immunity ${ }^{128}$ which may have supported the common law presumption of student non-residence.

Furthermore, even the informal immunity once conferred by authorities reluctant to invade the campus is fast crumbling. Many university officials now advocate the use of state and local police in

123. See generally Soglin v. Kaufman, 29j F. Supp. 978, 986-87 (W.D. Wis 1963); Note, Bringing the Vagueness Doctrine on Campus, 80 YALE L.J. 1261 (1971).

124. See generally Zanders v. Louisiana State Bd. of Educ, 281 F. Supp. 747, 750.57 (TV.D. La. 1968).

125. Id.

126. The Court noted that under the Federal Assimilative Crimes ACt, 18 U.S.C. \& 13 (1970), the NIH employees could be punished for violations of state law if, and only if, Congress had not pre-empted the field with federal criminal legislation. However, the Court conceded that the NIH residents were immune from state prosecutions and juries in that all trials under the act had to be brought by federal authorities in federal court. Evans v. Comman, 398 U.S. 419, 424-25 n.5 (1970).

127. See Goodman \& Niederhoffer, Universities and the Police: Force and Frecdom on Campus, 1 Yale Rev. L. \& Soc. Action 6 (Spring 1970).

128. See 4 W. Blackstone, Commentaries on the Law of ENGland 354-5j (Hammon ed. 1890). The students were also immune from the jurisdiction of the normal civil courts. See 3 id. at 112-13. 
campus disturbances ${ }^{120}$ and cooperate with the authorities in the enforcement of non-academic laws. ${ }^{130}$ Increased attention to the student by the police ${ }^{131}$ and elected officials ${ }^{132}$ indicates that the truce between town and gown is over. Indeed, the concern over campus unrest suggests that students, far from being immune from off-campus authority, are the focus of much of it.

Finally, the student who lives at college nine months of the year is subject to the police power of his college town and state far more than he is affected by the exercise of that power at his parents' home. Thus, the test of local power supports the census view and refutes a presumption of student non-residence.

\section{The Assumption of Immunity from Local Taxation}

The third frequently cited objection to the census definition is that students who reside in college dormitories are exempt from local taxation. Though the Supreme Court ${ }^{133}$ and the Twenty-Fourth Amendment ${ }^{134}$ have outlawed taxpaying as a suffrage qualification in and of itself, the Court in Evans made it clear that it is permissible to use the payment of taxes as an index of residence. ${ }^{135}$ In evaluating this objection, however, it must be stressed that student residence should not be examined with respect solely to municipal taxes. Voting rights are a state privilege, and registration, while often conducted at the local level, is a state action designed to enroll voters for all elections. ${ }^{136}$ Moreover, since local taxation is critically dependent on state expenditure policies, the proper question is the degree to which the student pays state as well as municipal taxes. Once this refinement has been made, the assumption that students, even those living on tax-exempt college property, are immune from local taxation becomes far less tenable.

129. See, e.g., Crackdown on Protestors, TIME, November 10, 1967, at 54; Notre Dame: Fifteen Minutes and Out, U.S. News \&: WORL.D RerORT, March 3, 1969, at 90; Camplis Crackdown: Colleges Strike Back at Violence, U.S. NEwS \& WORLD REPORT, Scptember 7, 1970 , at 16-20.

130. See, e.g., Note, College Searches and Seizures: Privacy and Due Process Problemis on Campus, 3 GA. L. REv. 426 (1969) (citing numerous cases where college authorities consented to the search of student rooms by local authorities enforcing non-academic laws). 131. See, e.g., Stevens, The Police, in LAw and Discipuine on CAMrus 107.13 (Holmes ed. 1971); Cahill, Law and Order on the Campus, F.B.I. ENFORCEMENT BuLl. 18.23 (March 1970); Carlson, Campus Security, F.B.L. ENFORCEMENT BulL. 17.22 (October 1970).

132. See, e.g., Note, Higher Education and the Student Unrest Provisions, 31 O1110 Sr. L.J. 111 (1970); But cf. Note, Equity on the Campus: The Limits of Injunctive Regula. tion of Universily Protest, 80 YALE L.J. 987 (1971).

133. Harper v. Virginia Bd. of Elections, 383 U.S. 663 (1966).

134. U.S. ConST. amend. XXIV.

135. Evans v. Cornman, 398 U.S. 419, 424 (1970).

136. Pope v. Williams, 193 U.S. 621,632 (1904). 
When the presumption against student residence was developed in the nineteenth century, state and local government was financed almost exclusively by property taxes. As late as 1927, seventy-eight per cent of all state and local revenue came from some form of property taxation. ${ }^{137}$ But by 1968, property taxes accounted for only thirty-nine per cent of such revenue, ${ }^{138}$ and that percentage is clearly declining. Since 1900 , state and local revenue needs have been met increasingly by taxes on sales, personal income, cigarettes, gasoline, and alcohol, all of which fall on the student as frequently as on any other resident. ${ }^{130}$

Even assuming that most students pay less in taxes than non-students, this fact may be more properly attributable to relative poverty than to residence. Furthermore, the typical student probably spends more on state and local consumer and income taxes at college than at his former home. Thus again, a test cited by the opponents of the census definition tends to support the Bureau's view that the student is more a resident of his college town than of his former home.

\section{The Assumption of Student Transiency}

A fourth objection to the census definition is that the student is a transient, likely to leave the college town when his studies have ended. However valid this assumption was in the nineteenth century, it must be reevaluated in the context of today's highly mobile socicty.

Unfortunately, there are no precise statistics on student mobility. We must therefore assume, as do those who contend the student is a transient, that the student will remain in the college town only long enough to obtain his degree. ${ }^{140}$ Based on this assumption and the distribution of students residing at two and four year colleges, the overall theoretical rate of annual student mobility is 26.5 per cent with an average tenure of forty-seven months. ${ }^{141}$ By comparison, the

137. Tabulated from statistics in U.S. Advisory Commisston on Interconernimestal. Relations, TAX-Overiapping in the United States 20, 36 (1964).

138. U.S. Bureau of the Census, Governarental Finances in 1968-1969, GF 69 No. 5. at 31 (September 1970).

139. The trend toward non-property taxation at the state level has been sivift and universal. As late as 1910, no state had an income, sales, cigarette or gasoline lax. See U.S. AdvisORY COMMISSION ON INTERCOVERNMENTAL RELATIONS, supta note 137, at 22-24. Today, forty-three states have some type of personal inconie tax, forty-six have sales taxes, and all fifty have excise taxes on cigarettes and gasoline. P.H STATE \& Locul. TAXES I 101 (1971).

140. Of course, some students do leave school before graduation, but of those who do, many, especially in large urban areas, stay on as college-town residents. And other students stay beyond their graduation as graduate students or workers. Thus while the assumption in the text is clearly open to refinement, it is a logical starting place in the absence of true statistics.

141. The annual mobility rate represents the percentage of the population which 
most recent annual mobility rate of all Americans was 19.1 per cent with an average tenure of sixty-three months. ${ }^{142}$ It is difficult to understand why this difference should justify such a clear presumption solely against student residence. The presumption becomes even less tenable when the student is compared to even more mobile groups. For example, the entire group aged twenty to twenty-four has a mobility rate of $\mathbf{4 5 . 6}$ per cent and a tenure of only twenty-five months; ${ }^{1.13}$ those unemployed, a group just as large as residential students, have a rate of 30.3 per cent and a tenure of thirty-nine months.1.4.

If there is any validity in inferring an intention to leave from such general mobility statistics, it would seem that all those twenty to twenty-four or all those unemployed should have to bear a burden of proof similar to the one imposed on students. But in an age where one's world is no longer confined to the town limits and the right to travel is a constitutionally protected one, ${ }^{145}$ such an assumption is clearly impermissible as a bar to suffrage rights. Once again, a realistic appraisal of an objection to the census definition has demonstrated the definition's validity, in this case by supporting the Bureau's contention that students should be treated as are other, equally mobile groups.

\section{Conclusions and Remedies}

Analysis of those factors most often cited by the critics of the census definition of student residence demonstrates that the Bureau's view is fundamentally correct. Therefore, in reconciling the conflict between the basis of apportionment and voting residence law, the latter should be altered to reflect the realities of contemporary student life. The definition of voting residence must conform to the simple observation that one "resides" where one habitually eats, sleeps, and carries on the other normal processes of one's life.

Such a definition has three advantages over the present standard.

moves each year; the tenure represents the average stay of a member of the population. Thus, if all students stayed in their college towns for four years, the annual mobility rate of all students would be twenty-five per cent and their tenure, forty-eight months. The theoretical rate stated in the text represents a weighted average between those students residing at four year colleges and those at two year schools. In 1966 there werc $1,725,000$ residential students pursuing four year degrees and 96,000 who were working for two year degrees. See U.S. BuREau of THE Census, Characteristics of Studenis ANd THEIR Colleges-October, 1966 P-20 No. 183, at 15 (May 22, 1969).

142. See U.S. Bureau of The Census, Moulity of Polulation in the United StaiesMARCH 1969 To MARCH 1970 P-20 No. 210, at 7 (January 15, 1971).

143. See id. at 10 .

144. See id. at 18 .

145. Shapiro v. Thompson, 394 U.S. 618 (1969). 
First, it suffices to end the conflict between apportionment and voting entitlement, thereby eliminating the malapportioned, college-town "rotten boroughs." Second, since the revised standard is relatively clear and subject to little interpretation, it will insure that the right to vote will not be subject to the "passing whim or impulse of an individual registrar."146 Finally, since it embodies the principle that one should vote for those officials who most affect his life, the revision is consistent with the Supreme Court's suffrage decisions. ${ }^{147}$ Local registrars should be required to qualify as voters all those who, by verifying their student status, prove that the census enumerates them as residents of the college town. ${ }^{148}$

However, legislatures need not await judicial action. At least one state already has a standard of voting residence which coincides with the census view. ${ }^{149}$ Should other states prove unwilling to redefine

146. Louisiana v. United States, 380 U.S. 145,153 (1965).

147. See, e.g., Phoenix v. Kolodziejski, 399 U.S. 204 (1970); Evans v. Comman, 393 U.S. 419 (1970); Cipriano v. City of Houma, 395 U.S. 701 (1969); Kramer v. Union Free School Dist. No. 15, 395 U.S. 621 (1969).

148. Members of the anmed forces stationed within the United States are the only other significant group of people considered local residents for census, and hence ap. portionment purposes, but then normally denied the right to register locally on resi. dency grounds. The simple residence standard advocated in the text would also eliminate this inconsistency in the law and thus remove the "roten borough" problem which also affects numerous "camp towns" throughout the nation.

It is, however, clearly incorrect to argue, as has Attorney General Mitchell, that according to the traditional tests of residence the serviceman is in the same position as the student and therefore to change the status of one by congressional fiat without altering the other is improper and unfair. See N.Y. Times, September 2, 1971, at 1, col. 7 .

First, members of the armed forces are almost totally immune from local police powicr while on their army posts because the Uniform Code of Alilitary Justice 3 special system of law which does not apply to other residents of the "camp town"-governs their conduct when "service-related." Relford v. Commandant, 401 U.S. 355 (1971); O'Callahan v. Parker, 395 U.S. 258 (1969). Second, servicemen are similarly immune from local income taxation and-to the extent that they confine their consumption to the postsales and excise taxation as well.

Finally, the transiency rate of those in the armed forces is considerably higher than that of students and others in our society (64.3 per cent, according to U.S. BUnesU of the Census, Mobility of Population in the United States, supra note 142, at 18) and it is a transiency the serviceman cannot control. Indeed, the fact that the serviceman is forced to come to the "camp town" was enough to distinguish servicemen from other purported domiciliaries in the mind of Justice Harlan. Carrington v. Rash, 380 U.S. 89, 100 (1965) (Harlan, J., dissenting).

Thus, while it may be the far better policy to completely overhaul the concept of voting residence to include servicemen as well as students in the population in which they live, the attributes traditionally used in determining residence suggest that identical treatment of the student and serviceman is not logically necessan;.

149. The term 'residence' ... for registration and roting purposes shall be con-

strued to mean that place at which a person habitually sleeps, keeps his or her

personal effects and has a regular place of lodging. Should a person have more than

1 residence... that place at which such person resides the greater part of the time

shall be his or her official residence...

Mich. Comp. Laws $\$ 168.11$ (a) (1967). This section was enacted in 1950 and originally applied to students as well as all other residents. But in 1963 the Iegislature excluded students from the statute's effect by enacting a legislative presumption of student non. 
their laws, Congress could force action by enacting legislation designed to protect the voting rights of students. Bills have already been intro. duced which would require the college-town registration, for federal elections, of any student who had been "attending an institution of higher education" for more than thirty days before the election. ${ }^{150}$ The history of the Twenty-Sixth Amendment suggests that such legislation would necessitate quick state action to avoid costly dual registration and voting procedures. 151

Whether judicial or legislative, prompt corrective action is crucial; the currently operative traditional presumption against student collegetown voting not only rests on dubious factual assumptions, but also represents an unconstitutional dilution of the "one-man, one-vote" principle.

residence. See MıсH. Comp. Laws § 168.11(b) (1967). However, the Michigan Supreme Court recently held this second section unconstitutional so that only the basic standard remains. Wilkins v. Bentley, Mich. 189 N.W.2d 423 (1971).

150. S.2240, 92d Cong., lst Sess. (1971) (Sen. Cranston); H.R. 10802, 92d Cong, Ist Sess. (1971) (Rep. Abzug); H.R. 11104, 92d Cong., 1st Sess. (1971) (Rep. Dellums).

151. See note 12 supra. 